\title{
Effects of chlorine deficiency in the field on leaf gas exchanges in the PB121 coconut hybrid
}

\author{
Serge Braconnier*, Xavier Bonneau \\ CIRAD-CP, BP 5035, 34032 Montpellier cedex 1, France
}

(Received 20 March 1998; accepted 11 August 1998)

\begin{abstract}
A study of leaf gas exchanges during the dry and rainy seasons confirmed the importance of the chloride ion in coconut. In the dry season, compared to a control, chloride deficiency led to lower stomatal conductance, hence a reduction in leaf gas exchanges. This resulted in less intense net photosynthesis and transpiration, which accounted for the poorer drought tolerance of chloride-deficient palms. During the dry season, even if not very intense, non-deficient palms maintained and even increased their stomatal conductance. This enabled them to increase leaf transpiration, hence responding to the increase in evaporative demand and maintaining a high level of net assimilation. Conversely, deficient palms reduced their stomatal conductance, leading to a drop in transpiration and net photosynthesis. Observations during the rainy season failed to reveal any effect of chloride deficiency on intrinsic photosynthesis. The chloride ion therefore seems to act primarily during the dry season, and in stomatal regulation. (@ Inra/Elsevier, Paris.)
\end{abstract}

chloride / drought / coconut / photosynthesis / stomatal conductance

Résumé - Effets d'une carence en chlorure au champ sur les échanges gazeux foliaires du cocotier hybride PB121. Une étude des échanges gazeux foliaires en saison sèche et en saison humide, a confirmé l'importance du rôle de l'ion chlorure chez le cocotier. En saison sèche, par rapport à un témoin, la carence en chlorure entraîne des conductances stomatiques plus faibles qui conduisent à la diminution des échanges gazeux. Il en résulte une photosynthèse et une transpiration moins intenses, expliquant la moins bonne tolérance à la sécheresse du cocotier carencé. En saison sèche, même peu intense, un cocotier non carencé, maintient et même augmente sa conductance. Ceci permet d'accroître sa transpiration, de répondre à l'augmentation de la demande évaporative et de maintenir une photosynthèse élevée. Au contraire, les plants carencés diminuent leur conductance, provoquant une baisse de transpiration et photosynthèse. Des observations en saison des pluies n'ont pas mis en évidence un effet d'une carence en chlorure sur la photosynthèse intrinsèque du cocotier. L'ion chlorure semble intervenir essentiellement en saison sèche, et sur la régulation stomatique. (C Inra/Elsevier, Paris.)

chlorure / sécheresse / cocotier / photosynthèse / conductance stomatique

Communicated by Gede Wibawa (Palembang, Indonesia)

\footnotetext{
* Correspondence and reprints
}

E-mail: braconnier@cirad.fr 


\section{INTRODUCTION}

The first work describing the major role of chloride in oil palm and coconut (Cocos nucifera L.) mineral nutrition dates back to 1971 [17, 18]. Since then, numerous articles have confirmed this positive effect on growth [11, 12, 16, 23], on yields [14, 15], on drought tolerance $[3,5,19]$, and on resistance to certain diseases [20].

Chloride was seen to play certain physiological roles in coconut. For instance, it was shown that the $\mathrm{Cl}^{-}$ion is of major importance in the mechanisms governing stomatal opening and closure [6]. As a result, it is also important for stomatal regulation, particularly during the dry season [8]. Moreover, its high concentration in coconut leaf tissues means that it acts as an osmoticum in maintaining tissue turgor during drought [7]. Furthermore, a certain number of studies on plants other than palms demonstrated the important role of chloride in photosynthesis [4] and particularly in photosystem II $[9,13]$.

The aim of this work was to confirm the importance of $\mathrm{Cl}^{-}$in coconut by detecting the effects of a chloride deficiency on coconut leaf gas exchanges in the field. We particularly studied its effect on net photosynthesis so as to determine whether the deficiency acted solely via stomatal regulation or was also involved in the intimate mechanisms of coconut photosynthesis.

\section{MATERIALS AND METHODS}

The study was carried out in fertiliser trial GB CC 08 at the MAC Gunung Batin plantation in South Lampung (south Sumatra), Indonesia. The trial, set up in December 1989 , is a $3^{3}$ factorial trial subdivided into two, with one replicate, studying three levels of $\mathrm{K}, \mathrm{Mg}$ and $\mathrm{Cl}$ nutrition $(0,1$ and 2) on two coconut hybrids: PB 121 and PB 111 [3]. The magnesium is applied as dolomite, potassium as potassium sulphate and chlorine as sodium chloride.

As it was not possible during our missions to study all 54 elementary plots, we selected four plots planted with PB 121, according to the applied treatments and as close as possible to one another (figure 1). Variations in soil characteristics are very low on this plantation [1], and we assumed that soil heterogeneity between the different plots could be neglected. The treatments were:

$$
\begin{aligned}
& * \mathrm{~K}_{0} \mathrm{Cl}_{2} \mathrm{Mg}_{1} \text { (plot 02); } \\
& * \mathrm{~K}_{2} \mathrm{Cl}_{2} \mathrm{Mg}_{2} \text { (plot 05); } \\
& * \mathrm{~K}_{2} \mathrm{Cl}_{0} \mathrm{Mg}_{0} \text { (plot 08); } \\
& * \mathrm{~K}_{0} \mathrm{Cl}_{0} \mathrm{Mg}_{2} \text { (plot 11). }
\end{aligned}
$$

As there was no problem of magnesium nutrition on the plantation, the comparison of these treatments was supposed to highlight the effect of chloride on foliar gas exchanges, and to emphasise its greater effect than potassium.

The observations were made over a dry season (September 1995) and a rainy season (February 1996), on the useful palms (= normal palms not in border rows) in each plot. Measurements were taken on the central part of ranks 9-12 leaves and each side of the first third of the leaflets. ADC infra-red gas analysers were used to study leaf gas exchanges: an LCA2 during the dry season and an LCA4 during the rainy season. To prevent overheating of the leaf tissues inserted into the chamber, only half the area was covered by the observed leaflet (i.e. 5.8 $\mathrm{cm}^{2}$ ) and the gas flow into the chamber was $450 \mathrm{~mL}$ $\min ^{-1}$.

Following a problem with PAR measurement during the September observations (dry season), net photosynthesis was only determined under saturating radiation $\left(\right.$ PAR $\left.>1000 \mathrm{~mol} \mathrm{~m}^{-2} \mathrm{~s}^{-1}\right)$.

Data were statistically analysed using a variance analysis method. For some analyses, we have regrouped under the names $\mathrm{Cl}_{0}$ and $\mathrm{Cl}_{2}$, the treatments $\mathrm{K}_{2} \mathrm{Cl}_{0} \mathrm{Mg}_{0}$ and $\mathrm{K}_{0} \mathrm{Cl}_{0} \mathrm{Mg}_{2}$, and treatments $\mathrm{K}_{0} \mathrm{Cl}_{2} \mathrm{Mg}_{1}$ and $\mathrm{K}_{2} \mathrm{Cl}_{2} \mathrm{Mg}_{2}$, respectively.

\section{RESULTS AND DISCUSSIONS}

The results of the latest analysis (carried out in May 1995) for the chosen plots are given in table I, which shows that $\mathrm{N}, \mathrm{P}, \mathrm{K}, \mathrm{Ca}, \mathrm{Mg}, \mathrm{Na}$ and $\mathrm{S}$ nutrition is good on the coconut palms in the four plots. The leaf contents for leaf 4 are thus not limiting, according to the results obtained previously under the same conditions. It is therefore reasonable to assume that the only factor that can differentiate between the plots is leaf chloride content: for instance, there are two plots with good chloride 


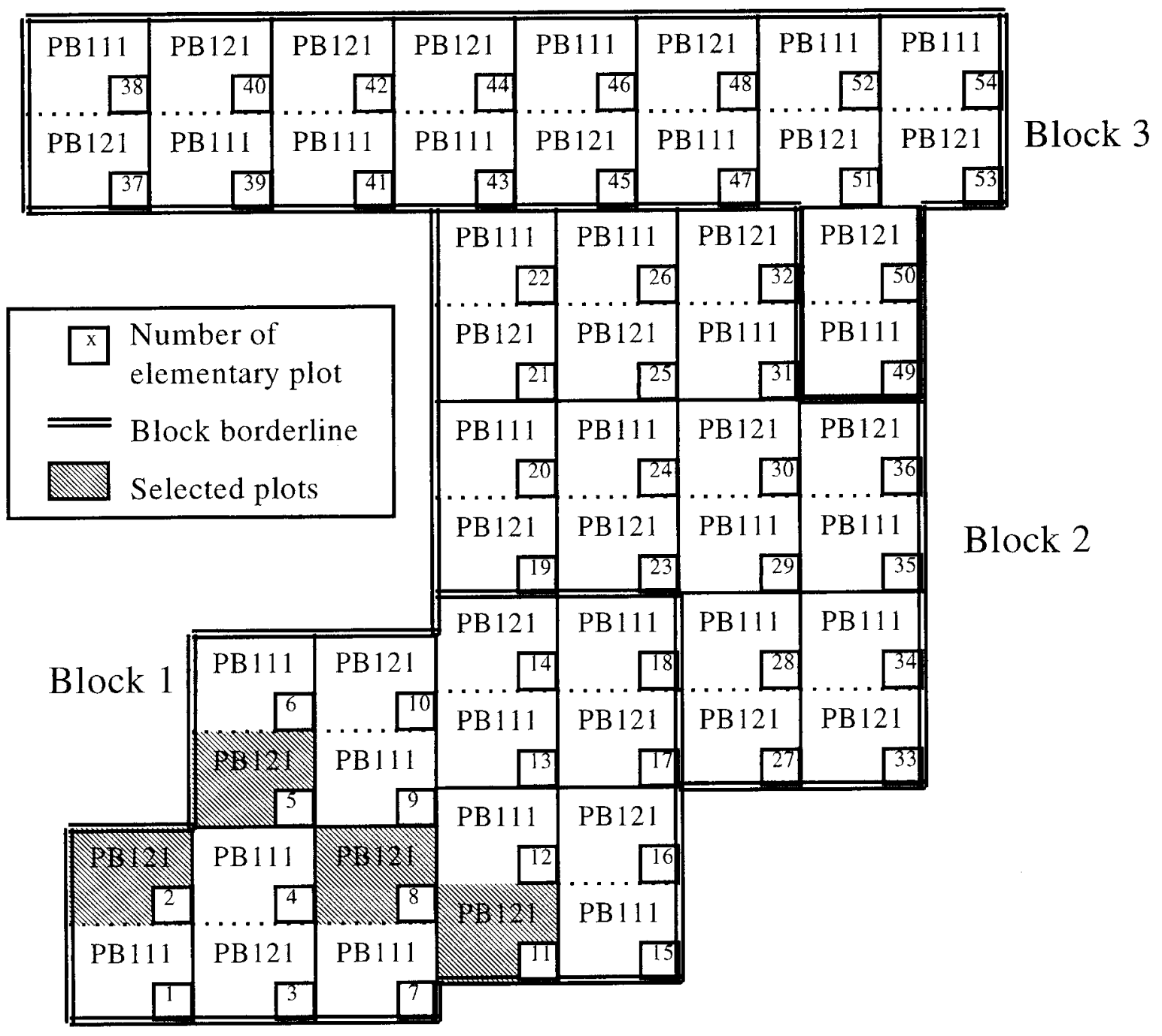

Figure 1. Layout of the GB CC 08 trial (MAC Plantations, Gunung Batin, south Sumatra).

nutrition (treatments $\mathrm{K}_{0} \mathrm{Cl}_{2} \mathrm{Mg}_{1}$ and $\mathrm{K}_{2} \mathrm{Cl}_{2} \mathrm{Mg}_{2}$ ), and two with a $\mathrm{Cl}^{-}$deficiency (treatments $\mathrm{K}_{2} \mathrm{Cl}_{0} \mathrm{Mg}_{0}$ and $\mathrm{K}_{0} \mathrm{Cl}_{0} \mathrm{Mg}_{2}$ ). However, it is worth noting that the high $\mathrm{Cl}^{-}$contents in treatments $\mathrm{K}_{0} \mathrm{Cl}_{2} \mathrm{Mg}_{1}$ and $\mathrm{K}_{2} \mathrm{Cl}_{2} \mathrm{Mg}_{2}$ are combined with high sodium contents in both cases. This can be attributed to the fact that chloride is applied as sodium chloride. However, these high sodium contents are not toxic for the palms, and have not yet had any effect on yields.
These analyses were performed at the end of the rainy season, but as Coomans [10] demonstrated that the variation coefficient of leaf $\mathrm{Cl}$ contents according to rainfall is $10 \%$, we can assume that a Cl-deficient coconut in May 1995 is still deficient during the drought season (September 1995). Even if there are some variations, the nutrient contents given in table $I$ are also valid for the drought period. This assumption is also supported by the fact that the drought period in 1995 was of a low intensity, with no water deficit for palms (table $I I$ ). 
Table I. Nutrient contents of the four selected plots. Observations carried out on leaf 4 in 1995 (data in \% of dry matter).

\begin{tabular}{lcccccccc}
\hline Treatment & $\mathrm{N}$ & $\mathrm{P}$ & $\mathrm{K}$ & $\mathrm{Ca}$ & $\mathrm{Mg}$ & $\mathrm{Na}$ & $\mathrm{Cl}$ & $\mathrm{S}$ \\
\hline $\mathrm{K}_{0} \mathrm{Cl}_{2} \mathrm{Mg}_{1}$ & 2.17 & 0.13 & 1.59 & 0.28 & 0.31 & 0.2 & 0.82 & 0.17 \\
$\mathrm{~K}_{2} \mathrm{Cl}_{2} \mathrm{Mg}_{2}$ & 2.15 & 0.13 & 2.18 & 0.24 & 0.25 & 0.10 & 0.74 & 0.19 \\
$\mathrm{~K}_{2} \mathrm{Cl}_{0} \mathrm{Mg}_{0}$ & 2.35 & 0.15 & 2.04 & 0.26 & 0.27 & 0.02 & 0.17 & 0.19 \\
$\mathrm{~K}_{0} \mathrm{Cl}_{0} \mathrm{Mg}_{2}$ & 2.35 & 0.16 & 1.86 & 0.30 & 0.33 & 0.03 & 0.15 & 0.17 \\
Critical level & 2.00 & 0.13 & 2.00 & nd & 0.17 & nd & 0.7 & 0.15 \\
\hline
\end{tabular}

nd $=$ non-determined.

Table II. Rainfall at MAC Plantation in 1995.

\begin{tabular}{|c|c|c|c|c|}
\hline Month & $\begin{array}{c}\text { Rainfall } \\
\text { (mm) }\end{array}$ & $\begin{array}{l}\text { Number of } \\
\text { rainy days }\end{array}$ & $\begin{array}{l}\text { Evaporation } \\
\left(\mathrm{mm} \mathrm{month}^{-1}\right)\end{array}$ & $\begin{array}{l}\text { Water deficit * } \\
\qquad(\mathrm{mm})\end{array}$ \\
\hline January & 391 & 20 & 167 & 0 \\
\hline February & 264 & 18 & 128 & 0 \\
\hline March & 339 & 21 & 111 & 0 \\
\hline April & 362 & 20 & 127 & 0 \\
\hline May & 144 & 12 & 112 & 0 \\
\hline June & 181 & 14 & 100 & 0 \\
\hline July & 152 & 14 & 114 & 0 \\
\hline August & 34 & 4 & 127 & 0 \\
\hline September & 173 & 8 & 140 & 0 \\
\hline October & 160 & 15 & 151 & 0 \\
\hline November & 138 & 18 & 116 & 0 \\
\hline December & 205 & 22 & 108 & 0 \\
\hline Total & 2543 & 186 & 1501 & 0 \\
\hline
\end{tabular}

* According to Surre [22].

\subsection{Stomatal conductance during the dry season}

The various values obtained for the four treatments are shown in tables $I I I$ and $I V$. Irrespective of the treatment, it is worth noting that the recorded stomatal conductance values were relatively low generally below $10 \mathrm{~mm} \mathrm{~s}^{-1}$ - and that they decreased significantly as the day wore on. In fact, the mean stomatal conductance values for treatments $\mathrm{K}_{0} \mathrm{Cl}_{2} \mathrm{Mg}_{1}$ and $\mathrm{K}_{2} \mathrm{Cl}_{2} \mathrm{Mg}_{2}$ fell from 7.3 and $8.3 \mathrm{~mm} \mathrm{~s}^{-1}$, respectively, in the morning to 6.4 and $4.8 \mathrm{~mm} \mathrm{~s}^{-1}$ in the afternoon. At the same time, the values fell from 6.6 to $3.4 \mathrm{~mm} \mathrm{~s}^{-1}$ and 6.0 to $3.9 \mathrm{~mm}$ $\mathrm{s}^{-1}$ for treatments $\mathrm{K}_{2} \mathrm{Cl}_{0} \mathrm{Mg}_{0}$ and $\mathrm{K}_{0} \mathrm{Cl}_{0} \mathrm{Mg}_{2}$, respectively. In each case, the differences were statistically significant.

These observations confirmed results obtained previously, which showed that during the dry season, coconut stomata close during the day [7].

A comparison of treatments $\mathrm{Cl}_{2}$ and $\mathrm{Cl}_{0}$ (table $I V)$ reveals that irrespective of when the measurement was taken, the mean stomatal conductance of $\mathrm{Cl}^{-}$-deficient palms was significantly lower than that of non-deficient palms. Moreover, during the day, the reduction in values was more obvious in the case of $\mathrm{Cl}^{-}$-deficient palms. In fact, conductance fell from 7.7 to $5.7 \mathrm{~mm} \mathrm{~s}^{-1}$ and from 6.3 to $3.7 \mathrm{~mm}$ 
Table III. Mean stomatal conductance values measured in the different treatments during the dry season.

\begin{tabular}{lll}
\hline & \multicolumn{2}{l}{ Stomatal conductance $\left(\mathrm{mm} \mathrm{s}^{-1}\right)$} \\
\hline Treatment & Morning & Afternoon \\
\hline $\mathrm{K}_{0} \mathrm{Cl}_{2} \mathrm{Mg}_{1}$ & $7.3 \pm 4.4$ & $6.4 \pm 1.1^{*}$ \\
$\mathrm{~K}_{2} \mathrm{Cl}_{2} \mathrm{Mg}_{2}$ & $8.3 \pm 5.2$ & $4.8 \pm 1.1^{*}$ \\
$\mathrm{~K}_{2} \mathrm{Cl}_{0} \mathrm{Mg}_{0}$ & $6.6 \pm 3.1$ & $3.4 \pm 1.2^{*}$ \\
$\mathrm{~K}_{0} \mathrm{Cl}_{0} \mathrm{Mg}_{2}$ & $6.0 \pm 2.1$ & $3.9 \pm 1.4^{*}$ \\
\hline
\end{tabular}

Each mean is obtained from 70 to 110 measurements.

* Difference between morning and afternoon was statistically highly significant.

Table IV. Comparison of treatments $\mathrm{Cl}_{2}$ to $\mathrm{Cl}_{0}$ in the dry season.

\begin{tabular}{llc}
\hline & \multicolumn{2}{l}{ Stomatal conductance $\left(\mathrm{mm} \mathrm{s}^{-1}\right)$} \\
\hline Treatment & Morning & Afternoon \\
\hline $\mathrm{Cl}_{2}$ & $7.7 \pm 2.4$ & $5.7 \pm 1.4^{*}$ \\
$\mathrm{Cl}_{0}$ & $6.3 \pm 2.5$ & $3.7 \pm 1.4^{*}$ \\
$\Delta \mathrm{Cl}_{2}-\mathrm{Cl}_{0}$ & 1.3 (HS) & 2.0 (HS) \\
\hline
\end{tabular}

HS $=$ highly significant difference.

* Difference between morning and afternoon was highly significant.

Table V. Mean net assimilation values measured in the different treatments in the dry season.

\begin{tabular}{lcc}
\hline & \multicolumn{2}{c}{ Net assimilation $\left(\mu \mathrm{mol} \mathrm{CO}_{2} \mathrm{~m}^{-2} \mathrm{~s}^{-1}\right)$} \\
\hline Treatment & Morning & Afternoon \\
\hline $\mathrm{K}_{0} \mathrm{Cl}_{2} \mathrm{Mg}_{1}$ & $12.4 \pm 2.0$ & $12.5 \pm 1.7$ \\
$\mathrm{~K}_{2} \mathrm{Cl}_{2} \mathrm{Mg}_{2}$ & $11.9 \pm 2.3$ & $12.1 \pm 1.4$ \\
$\mathrm{~K}_{2} \mathrm{Cl}_{0} \mathrm{Mg}_{0}$ & $10.2 \pm 1.9$ & $8.3 \pm 1.9^{*}$ \\
$\mathrm{~K}_{0} \mathrm{Cl}_{0} \mathrm{Mg}_{2}$ & $10.5 \pm 2.2$ & $8.7 \pm 2.5^{*}$ \\
\hline
\end{tabular}

Each mean is obtained from 70 to 110 measurements.

* Difference between morning and afternoon was highly significant.

$\mathrm{S}^{-1}$ for control and $\mathrm{Cl}^{-}$-deficient palms, respectively. In the course of the day, this corresponded to a mean reduction of 26 and $41 \%$ for $\mathrm{Cl}_{2}$ and $\mathrm{Cl}_{0}$, respectively.
Table VI. Comparison of net assimilation, in the dry season, on chloride-deficient or non-deficient palms.

\begin{tabular}{lcc}
\hline & Net assimilation $\left(\mu \mathrm{mol} \mathrm{CO}_{2} \mathrm{~m}^{-2} \mathrm{~s}^{-1}\right)$ \\
\hline Treatment & Morning & Afternoon \\
\hline $\mathrm{Cl}_{2}$ & $12.2 \pm 1.8$ & $12.3 \pm 1.6$ \\
$\mathrm{Cl}_{0}$ & $10.4 \pm 2.0$ & $8.5 \pm 2.5^{*}$ \\
$\Delta \mathrm{Cl}_{2}-\mathrm{Cl}_{0}$ & 1.8 (HS) & $3.8(\mathrm{HS})$ \\
\hline
\end{tabular}

HS = highly significant difference.

* Idem table V)

These results therefore confirm the importance of the role of the $\mathrm{Cl}^{-}$ion in stomatal regulation mechanisms during the dry season. When water supply conditions become difficult, a chloride deficiency results in lesser stomatal opening right from the morning, and in more intense stomatal closure in the course of the day.

\subsection{Net assimilation during the dry season}

The net assimilation values recorded at the same time as the conductance values are shown in tables $V$ and $V I$. It is clear (table $V$ ) that the means per treatment do not exceed $12.5 \mu \mathrm{mol} \mathrm{CO}_{2} \mathrm{~m}^{-2} \mathrm{~s}^{-1}$, which is lower than the usual value of around 16 $\mu \mathrm{mol} \mathrm{CO} \mathrm{CO}^{-2} \mathrm{~s}^{-1}$ for this variety [21]. This is due to the fact that the measurements were made during the dry season. However, it is clear that in the morning, net photosynthesis on non-deficient palms was significantly higher than on $\mathrm{Cl}^{-}$-deficient palms. In fact, the mean value was $12.2 \mu \mathrm{mol} \mathrm{CO} \mathrm{C}^{-2} \mathrm{~s}^{-1}$ for the controls $\left(+\mathrm{Cl}^{-}\right)$, compared to $10.4 \mu \mathrm{mol} \mathrm{CO} \mathrm{m}^{-2}$ $\mathrm{s}^{-1}$ for the deficient palms. The difference was highly significant and increased in the afternoon owing to the reduction in net photosynthesis of the $\mathrm{Cl}^{-}$deficient palms (from 10.4 to $8.5 \mu \mathrm{mol} \mathrm{CO}_{2} \mathrm{~m}^{-2}$ $\mathrm{s}^{-1}$ ), whereas net photosynthesis remained stable throughout the day in the control palms (table $V I$ ).

In the dry season, a chloride deficiency in coconut thus leads to less intense photosynthesis in the morning, and to a statistically significant fall 
during the day. These effects can be explained by the previous observations of stomatal conductance. In fact, compared to control palms, the conductance values for $\mathrm{Cl}^{-}$-deficient palms were lower in the morning, and fell more markedly during the day, as a result of stomatal closure leading to a reduction in gas exchanges.

The falls in net photosynthesis observed on $\mathrm{Cl}^{-}$deficient coconut palms in the event of drought can thus be attributed to the reduction in stomatal conductance. However, the possibility of a depressive effect on the photosynthesis mechanisms proper cannot be ruled out. It is in fact possible that the two effects (direct on photosynthesis and indirect via stomatal regulation) may be combined.
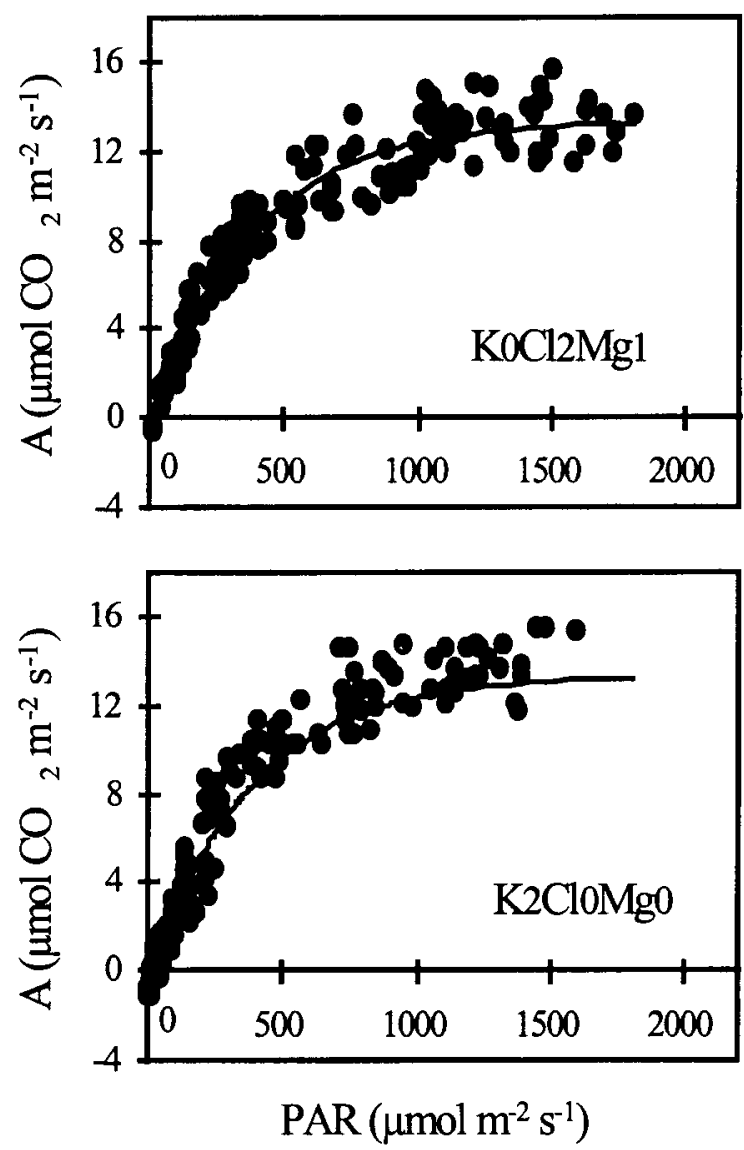

\subsection{Observations during the rainy season}

Net photosynthesis saturation by radiation was plotted for each treatment (figure 2). This figure shows that the experimental points were closely grouped, and that their distribution was apparently identical for all four treatments. The saturation plateau was around $13.5 \mu \mathrm{mol} \mathrm{CO}_{2} \mathrm{~m}^{-2} \mathrm{~s}^{-1}$, and was reached for radiations of over $1000 \mu \mathrm{mol} \mathrm{m} \mathrm{m}^{-2} \mathrm{~s}^{-1}$. Although the water supply conditions were good, it is important to note that maximum net assimilation did not reach the values recorded for identical planting material in the Ivory Coast, viz. around $16 \mu \mathrm{mol}$ $\mathrm{CO}_{2} \mathrm{~m}^{-2} \mathrm{~s}^{-1}$.
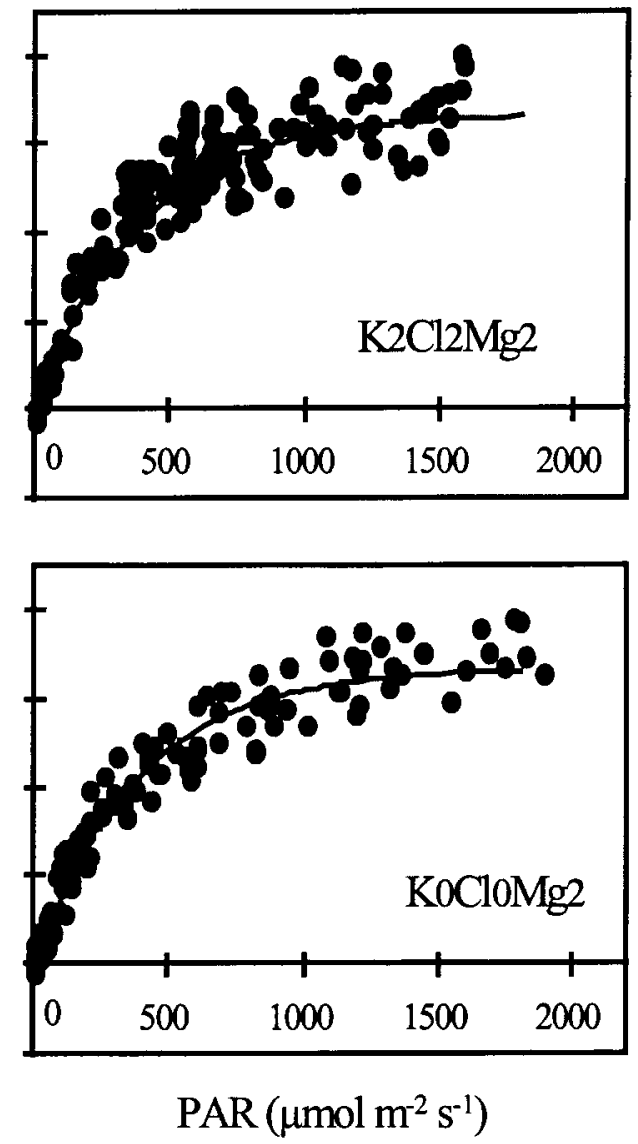

Figure 2. Net photosynthesis saturation by photosynthetic active radiation. Adjustments: $\mathrm{K}_{0} \mathrm{Cl}_{2} \mathrm{Mg}_{1}: \mathrm{Y}=13.37 \times(1-\exp (-0.0026 \times$ $(\mathrm{PAR}-8.69))) ; \mathrm{K}_{2} \mathrm{Cl}_{2} \mathrm{Mg}_{2}: \mathrm{Y}=13.20 \times(1-\exp (-0.0032 \times(\mathrm{PAR}-16.1))) ; \mathrm{K}_{2} \mathrm{Cl}_{0} \mathrm{Mg}_{0}: \mathrm{Y}=14.13 \times(1-\exp (-0.0029 \times(\mathrm{PAR}-$ $22.8))) \mathrm{K}_{0} \mathrm{Cl}_{(0} \mathrm{Mg}_{2}: \mathrm{Y}=13.65 \times(1-\exp (-0.0025 \times(\mathrm{PAR}-4.25)))$. 
For each treatment, we sought the best negative exponential adjustment of the following type:

$$
\mathrm{A}=\operatorname{Amax} \times(1-\exp (-\varepsilon \times(\mathrm{PAR}-\mathrm{C})))
$$

where $\mathrm{A}=$ net photosynthesis, Amax is the maximum net photosynthesis, $\mathrm{C}=$ radiation compensation point, $\varepsilon$ is a coefficient.

The values for the different factors and their confidence intervals are shown in table VII. The four adjustments were very similar, and the statistical analysis led us to conclude that the curves were identical. Irrespective of whether there was a chloride deficiency, the curve for net photosynthesis saturation by radiation was identical for coconut.

The mean values for net assimilation, stomatal conductance and transpiration measured during the rainy season with saturating radiation (PAR $>1000$ $\mu \mathrm{mol} \mathrm{m}^{-2} \mathrm{~s}^{-1}$ ) are given in table VIII. Any significant difference among the four treatments was detected.

Under non-limiting water supply conditions, chloride deficiency does not therefore seem to have

Table VII. Values for the different parameters of the adjustment curve $A=A \max \times(1-\exp (-\varepsilon \times(P A R-C)))$, and confidence interval (at $5 \%$ ) for each treatment.

\begin{tabular}{|c|c|c|c|c|}
\hline \multirow[b]{2}{*}{ Treatment } & \multirow[b]{2}{*}{ Parameter } & \multirow[b]{2}{*}{ Estimate } & \multicolumn{2}{|c|}{ Confidence interval } \\
\hline & & & Minimum & Maximum \\
\hline \multirow{3}{*}{$\mathrm{K}_{0} \mathrm{Cl}_{2} \mathrm{Mg}_{1}$} & Amax & 13.37 & 12.96 & 13.77 \\
\hline & $\mathrm{C}$ & 8.69 & -6.04 & 23.41 \\
\hline & $\varepsilon$ & 0.0026 & 0.0023 & 0.0029 \\
\hline \multirow{3}{*}{$\mathrm{K}_{2} \mathrm{Cl}_{2} \mathrm{Mg}_{2}$} & Amax & 13.20 & 12.75 & 13.65 \\
\hline & C & 16.10 & 3.71 & 28.49 \\
\hline & $\varepsilon$ & 0.0032 & 0.0028 & 0.0036 \\
\hline \multirow{3}{*}{$\mathrm{K}_{2} \mathrm{Cl}_{0} \mathrm{Mg}_{0}$} & Amax & 14.13 & 13.65 & 14.61 \\
\hline & $\mathrm{C}$ & 22.88 & 14.77 & 30.10 \\
\hline & $\varepsilon$ & 0.0029 & 0.0026 & 0.0032 \\
\hline \multirow{3}{*}{$\mathrm{K}_{0} \mathrm{Cl}_{0} \mathrm{Mg}_{2}$} & $A \max$ & 13.65 & 13.15 & 14.14 \\
\hline & $\mathrm{C}$ & 4.25 & -7.24 & 15.74 \\
\hline & $\varepsilon$ & 0.0025 & 0.0022 & 0.0028 \\
\hline
\end{tabular}

Table VIII. Mean values for net assimilation, transpiration and stomatal conductance with saturating radiation, during the rainy season. .

\begin{tabular}{lccc}
\hline & $\begin{array}{c}\text { Net assimilation } \\
\left(\mu \mathrm{mol} \mathrm{CO} \mathrm{m}^{-2} \mathrm{~s}^{-1}\right)\end{array}$ & $\begin{array}{c}\text { Transpiration } \\
\left(\mathrm{mmol} \mathrm{H}_{2} \mathrm{O} \mathrm{m}^{-2} \mathrm{~s}^{-1}\right)\end{array}$ & $\begin{array}{c}\text { Stomatal conductance } \\
\left(\mathrm{mm} \mathrm{s}^{-1}\right)\end{array}$ \\
\hline $\mathrm{K}_{0} \mathrm{Cl}_{2} \mathrm{Mg} 1$ & $13.4 \pm 1.2$ & $3.9 \pm 1.1$ & $6.6 \pm 1.2$ \\
$\mathrm{~K}_{2} \mathrm{Cl}_{2} \mathrm{Mg}_{2}$ & $13.2 \pm 1.4$ & $3.6 \pm 0.7$ & $6.7 \pm 1.6$ \\
$\mathrm{~K}_{2} \mathrm{Cl}_{0} \mathrm{Mg}_{0}$ & $13.8 \pm 1.2$ & $3.6 \pm 0.7$ & $7.5 \pm 1.8$ \\
$\mathrm{~K}_{0} \mathrm{Cl}_{0} \mathrm{Mg}_{2}$ & $13.4 \pm 1.3$ & $4.0 \pm 0.7$ & $6.7 \pm 1.5$ \\
\hline
\end{tabular}

Each value is obtained from about 30 measurements. 
a depressive effect on the intimate mechanisms of coconut photosynthesis. The depressive effect on assimilation only seems to occur during the dry season, and probably results from reduced stomatal conductance.

\subsection{Comparison between dry and rainy seasons}

To prevent any stomatal limitation due to increase in water vapour deficit during the day, the data used for this comparison were those measured with saturating radiation in February 1996 (rainy season), and those recorded in the morning in
September 1995 (dry season). Table IX gives the mean values for net assimilation, stomatal conductance and transpiration for each treatment. The results obtained depending on the chloride nutrition are shown in table $X$.

As regards stomatal conductance, it was seen (tables $I X$ and $X$ ) that the values measured on deficient coconut palms in the dry season were lower than those recorded in the rainy season. This may account for the significant difference between the net photosynthesis values. In fact, compared to the rainy season, net photosynthesis was 26 and $22 \%$ lower in the dry season for the coconut palms in plots 8 and 11, respectively. However, for non-deficient palms, the conductance values recorded in September were higher than those in February, and

Table IX. Comparison of the means for net assimilation, transpiration and stomatal conductance measured in the dry season and in the rainy season, in the four treatments.

\begin{tabular}{|c|c|c|c|c|c|c|}
\hline \multirow[b]{2}{*}{ Treatment } & \multicolumn{2}{|c|}{$\begin{array}{l}\text { Net assimilation } \\
\left(\mu \mathrm{mol} \mathrm{CO} \mathrm{CO}^{-2} \mathrm{~s}^{-1}\right)\end{array}$} & \multicolumn{2}{|c|}{$\begin{array}{c}\text { Transpiration } \\
\left(\mathrm{mmol} \mathrm{H} \mathrm{O} \mathrm{m}^{-2} \mathrm{~s}^{-1}\right)\end{array}$} & \multicolumn{2}{|c|}{$\begin{array}{l}\text { Stomatal conductance } \\
\qquad\left(\mathrm{mm} \mathrm{s}^{-1}\right)\end{array}$} \\
\hline & $\begin{array}{l}\text { Sept. } \\
\text { (dry) }\end{array}$ & $\begin{array}{l}\text { Feb. } \\
\text { (rainy) }\end{array}$ & $\begin{array}{l}\text { Sept. } \\
\text { (dry) }\end{array}$ & $\begin{array}{l}\text { Feb. } \\
\text { (rainy) }\end{array}$ & $\begin{array}{l}\text { Sept. } \\
\text { (dry) }\end{array}$ & $\begin{array}{l}\text { Feb. } \\
\text { (rainy) }\end{array}$ \\
\hline $\mathrm{K}_{0} \mathrm{Cl}_{2} \mathrm{Mg}_{1}$ & $12.4 \pm 2.0$ & $13.4 \pm 1.2 *$ & $4.4 \pm 1.0$ & $3.9 \pm 1.1 *$ & $7.3 \pm 4.4$ & $6.6 \pm 1.2 *$ \\
\hline $\mathrm{K}_{2} \mathrm{Cl}_{2} \mathrm{Mg}_{2}$ & $11.9 \pm 2.3$ & $13.2 \pm 1.6 *$ & $4.1 \pm 0.4$ & $3.6 \pm 0.7 *$ & $8.3 \pm 5.2$ & $6.7 \pm 1.6 *$ \\
\hline $\mathrm{K}_{2} \mathrm{Cl}_{0} \mathrm{Mg}_{0}$ & $10.2 \pm 1.9$ & $13.7 \pm 1.3 *$ & $3.7 \pm 1.3$ & $3.7 \pm 0.6$ & $6.6 \pm 3.1$ & $7.5 \pm 1.8 *$ \\
\hline $\mathrm{K}_{0}^{2} \mathrm{Cl}_{0} \mathrm{Mg}_{2}$ & $10.5 \pm 2.2$ & $13.4 \pm 1.4 *$ & $3.7 \pm 0.9$ & $4.0 \pm 0.7 *$ & $6.0 \pm 2.1$ & $6.7 \pm 1.5 *$ \\
\hline
\end{tabular}

* Value statistically different from that for September (at $5 \%$ ).

Each mean is obtained from 30 to 60 measurements.

Table X. Comparison of the means for net assimilation, transpiration and stomatal conductance measured in the dry season and in the rainy season, depending on chloride nutrition.

\begin{tabular}{|c|c|c|c|c|c|c|}
\hline & \multicolumn{2}{|c|}{$\begin{array}{l}\text { Net assimilation } \\
\left(\mu \mathrm{mol} \mathrm{CO}_{2} \mathrm{~m}^{-2} \mathrm{~s}^{-1}\right)\end{array}$} & \multicolumn{2}{|c|}{$\begin{array}{c}\text { Transpiration } \\
\left(\mathrm{mmol} \mathrm{H}_{2} \mathrm{O} \mathrm{m}^{-2} \mathrm{~s}^{-1}\right)\end{array}$} & \multicolumn{2}{|c|}{$\begin{array}{l}\text { Stomatal conductance } \\
\left(\mathrm{mm} \mathrm{s}^{-1}\right)\end{array}$} \\
\hline & $\begin{array}{l}\text { Sept. } \\
\text { (dry) }\end{array}$ & $\begin{array}{l}\text { Feb. } \\
\text { (rainy) }\end{array}$ & $\begin{array}{l}\text { Sept. } \\
\text { (dry) }\end{array}$ & $\begin{array}{l}\text { Feb. } \\
\text { (rainy) }\end{array}$ & $\begin{array}{l}\text { Sept. } \\
\text { (dry) }\end{array}$ & $\begin{array}{l}\text { Feb. } \\
\text { (rainy) }\end{array}$ \\
\hline $\mathrm{Cl}_{2}$ & $12.2 \pm 1.8$ & $13.2 \pm 1.3 *$ & $4.2 \pm 0.9$ & $3.9 \pm 1.0 *$ & $7.7 \pm 2.4$ & $6.7 \pm 1.4 *$ \\
\hline $\mathrm{Cl}_{0}^{-}$ & $10.4 \pm 2.1$ & $13.5 \pm 1.2 *$ & $3.7 \pm 1.1$ & $3.9 \pm 0.7$ & $6.3 \pm 2.5$ & $7.1 \pm 1.7 *$ \\
\hline
\end{tabular}

* Value statistically different from that for September (at $5 \%$ ). 
were combined with greater transpiration and with a small drop in net assimilation ( -6 and $-11 \%$ for plots $\mathrm{K}_{0} \mathrm{Cl}_{2} \mathrm{Mg}_{1}$ and $\mathrm{K}_{2} \mathrm{Cl}_{2} \mathrm{Mg}_{2}$ treatments, respectively). This last phenomenon is surprising, and we do not yet know the reason behind it.

In chloride-deficient palms, leaf gas exchanges decreased during the dry season compared to the rainy season, leading to a drop in conductance and in net assimilation. Under the same conditions, the control palms succeeded in maintaining normal conductance, and even in increasing it to satisfy the higher evaporative demand, hence keeping a high level of net assimilation. $\mathrm{A} \mathrm{Cl}^{-}$deficiency thus had an adverse effect on the carbohydrate nutrition of coconut palms during the dry season.

\section{CONCLUSION}

These observations of gas exchanges in coconut during the dry season and the rainy season confirmed the important role of chloride in this palm. In the dry season, a chloride deficiency has a depressive effect on gas exchanges right from the morning, which worsens as the day wears on. This results in a drop in stomatal conductance, transpiration and net photosynthesis.

In the event of moderate drought, coconut palms not suffering from a chloride deficiency respond to higher evaporative demand by increasing their stomatal conductance and transpiration, and by maintaining a reasonable level of net photosynthesis. Under the same conditions, deficient palms react by reducing their stomatal conductance and net photosynthesis, hence expressing a state of stress. The $\mathrm{Cl}^{-}$ion therefore enables coconut palms to withstand the dry season, by maintaining a relatively high level of leaf gas exchanges.

The observations made during the rainy season did not reveal a depressive effect of chloride deficiency on gas exchanges, provided water supply was not limiting. The curves for net photosynthesis saturation by light for $\mathrm{Cl}^{-}$-deficient coconut palms were not statistically different from those for control palms.
Chloride deficiency in coconut therefore only seems to have an effect in the dry season, even if it is not very intense, and results in decreased leaf gas exchanges by acting on stomatal regulation.

Lastly, this work confirmed that for coconut, sodium chloride is a good alternative to potassium chloride for correcting chlorine deficiencies $[2,14]$.

Acknowledgements: This work was conducted under an STD3 project (Contract no. TS3 CT920132), funded by the European Union. We should also like to thank Multi Agro Corporation (Indonesia) for allowing us to work at its Gunung Batin plantation.

\section{REFERENCES}

[1] Bonneau X., Recherche sur les facteurs limitant la production végétale en conditions de stress hydrique: cas du cocotier à Gunung Batin (Indonésie): rôle du chlore dans l'économie de l'eau, thèse, Institut national agronomique Paris Grignon, Paris, 1998, 194 p.

[2] Bonneau X., Boutin D., Bourgoing R., Sugarianto J., Sodium chloride, an ideal fertilizer for coconut palms, Plantations Recherche Développement 4 (1997) 336-346.

[3] Bonneau X., Ochs R., Kitu W.T., Yuswohadi, Le chlore: un élément essentiel de la nutrition minérale des cocotiers hybrides dans le Lampung (Indonésie), Oléagineux 48 (1993) 179-190.

[4] Bove J.M., Bove C., Whatley F.R., Arnon D.J., Chloride requirement for oxygen evolution in photosynthesis, Z. Naturforsch. 18B (1963) 683-688.

[5] Braconnier S., Physiologie de la nutrition en chlorure chez le palmier B huile et le cocotier, thèse, université des sciences et techniques du Languedoc, Montpellier, 1988, 207 p.

[6] Braconnier S., D'Auzac J., Étude anatomique et mise en évidence cytologique des mouvements de potassium et de chlore associés B l'ouverture des stomates de palmier B huile et de cocotier, C. R. Acad. Sci. Paris Série III (1989) 457-462.

[7] Braconnier S., D'Auzac J., Effet d'une carence en chlorure au champ chez le cocotier hybride PB 121 , Oléagineux 44 (1989) 467-474. 
[8] Braconnier S., D'Auzac J., Chloride and stomatal conductance in coconut, Plant Physiol. Biochem. 28 (1990) 105-111.

[9] Coleman W.J., Govindjee, A model for the mechanism of chloride activation of oxygen evolution in photosystem II, Photosynthesis Res. 13 (1987) 199-223.

[10] Coomans P., Variations saisonnières de la composition minérale des feuilles de cocotier, Oléagineux 29 (1974) 297-304.

[11] Daniel C., Manciot R., La nutrition en chlore des jeunes cocotiers aux Nouvelle-Hébrides, Oléagineux 28 (1973) 71-72.

[12] Eschbach J.M., Massimino D., Mendoza A.M.R., Effet d'une carence en chlore sur la germination, la croissance et la photosynthèse du Cocotier, Oléagineux 37 (1982) 115-125.

[13] Kelley P.M., Izawa S., The role of chloride in photosystem II. I. Effect of chloride ion on photosystem II electron transport and on hydroxylamine inhibition, Biochim. Biophys. Acta 502 (1978) 198-210.

[14] Magat S.S., Margate R.Z., Habana J.A., Effects of increasing rates of sodium chloride (common salt) fertilisation on coconut palms grown under an inland soil (Tropudalfs), of Mindanao, Philippines, Oléagineux 43 (1988) 13-18.

[15] Magat S.S., Pradones G.D., Improvement of coconut production by combined potassium chloride and ammonium sulfate fertilisation in a low-yielding area of Northern Mindanao, Philipp. J. Coconut Stud. 3 (1991) $37-44$.
[16] Margate R.Z., Magat S.S., Growth response of coconut seedlings from seednuts collected from palms fertilised with sodium chloride (common salt), Philipp. J. Coconut Stud. 13 (1988) 1-5.

[17] Ollagnier M., Ochs R., Le chlore, nouvel élément essentiel dans la nutrition du Palmier $B$ huile, Oléagineux 26 (1971) 1-15.

[18] Ollagnier M., Ochs R., La nutrition en chlore du Palmier B huile et du Cocotier, Oléagineux 26 (1971) 367-372.

[19] Ollagnier M., Ochs R., Pomier M., Taffin G., Action du chlore sur le cocotier hybride PB-121 en Côted'Ivoire et en Indonésie. Développement, tolérance à la sécheresse, production, Oléagineux 38 (1983) 309-321.

[20] Renard J.L., Brahmana D., Rognon F., Comportement du cocotier hybride Nain Jaune $\times$ Grand Ouest Africain vis-à-vis du stem bleeding en Indonésie. Mise en évidence du rôle du chlore dans l'expression des symptômes, Oléagineux 39 (1984) 311-319.

[21] Repellin A., Influence du déficit hydrique sur la physiologie des palmes de diverses variétés de cocotier (Cocos nucifera L.): évolution des paramètres hydriques, des échanges gazeux et de la composition lipidique des membranes, thèse, biologie végétale tropicale, Université Paris 7 Denis Diderot, Paris, 242 p.

[22] Surre C., Les besoins en eau du palmier à huile. Calcul du bilan de l'eau et ses applications, Oléagineux 23 (1968) 165-167.

[23] Uexkull, H.R.V., Chloride in the nutrition of palm trees, Oléagineux 40 (1985) 67-74. 